\title{
Porous Si (111) Fabrication Using Electrochemical Anodization: Effects of Electrode Distance and Current Density
}

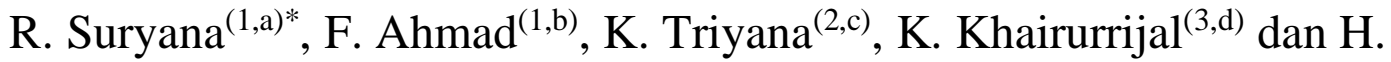 \\ Susanto $^{(4, \mathrm{e})}$ \\ ${ }^{(1)}$ Department of Physics, Faculty of Mathematics and Natural Sciences, Universitas Sebelas Maret, \\ Surakarta, Indonesia, 57126 \\ ${ }^{(2)}$ Department of Physics, Faculty of Mathematics and Natural Sciences, Universitas Gadjah Mada, \\ Yogyakarta, Indonesia, 55281 \\ ${ }^{(3)}$ Department of Physics, Faculty of Mathematics and Natural Sciences, Institut Teknologi Bandung, \\ Bandung, Indonesia, 40132 \\ ${ }^{(4)}$ Department of Chemical Engineering, Faculty of Engineering, Universitas Diponegoro, Semarang, \\ Indonesia, 50275 \\ Email: ${ }^{\left({ }^{*}\right)}$ rsuryana@staff.uns.ac.id, ${ }^{(b)}$ fauzi.ahmad.bogas@gmail.com, ${ }^{(c)}$ triyana@ugm.ac.id, \\ ${ }^{(d)}$ krijal@fi.itb.ac.id, ${ }^{(e)}$ heru.susanto@undip.ac.id
}

Diterima (19 November 2020), Direvisi (31 Januari 2021)

\begin{abstract}
Porous silicon (PSi) has been developed for many applications, such as gas and humidity sensors. Various methods are available to fabricate PSi, and electrochemical anodization is expected due to its low cost and easy use. Current density, etching/anodization time, type of etching solution, and electrode distance are the parameters determining resulting pores. The substrate used an n-type silicon wafer with (111)-orientation and resistivity of 1.5-4.5 $\Omega . \mathrm{cm}$ with a size of $1.5 \times 1 \mathrm{~cm}^{2}$. The cleaning process of the samples employed the $R C A$ cleaning procedure. Conductive contacts required for the electrochemical anodization were aluminum on the samples. The electrodes were the Si sample acting as anode and platinum (Pt) electrode as a cathode. The etching solution used a mixture of HF (40\%) and ethanol (99\%) with a 1:1 ratio. The electrode distance was 1.5, 2.0, and $2.5 \mathrm{~cm}$. The current density for each electrode distance was 10,30 , and $50 \mathrm{~mA} / \mathrm{cm}^{2}$ with an anodization time of $30 \mathrm{~min}$. SEM and UV-Vis characterizations were applied to obtain surface morphology and reflectance, respectively. For all samples, the reflectance of PSi was lower than the reflectance of the original silicon surface (no pores). This condition indicates that the PSi is suitable as an anti-reflective layer in a solar cell. However, the PSi of reflectance curves has irregular shapes as a function of wavelength for different electrode distance and the current density. The SEM images confirmed that the pores formed on the silicon surface were inhomogeneous. The pore size decreased with the increase of the electrode distance while it increased with the increase of the current density. There was a correlation between pores size and reflectance at specific wavelength numbers.
\end{abstract}

Keywords: Anodization, Reflectance, Porous silicon, Si(111)

Abstrak. Silikon berpori (PSi) telah berkembang pada banyak aplikasi seperti sensor gas dan kelembaban. Banyak metode dalam pembuatan PSi dan anodisasi elektrokimia merupakan metode yang umumnya digunakan karena murah dan mudah. Parameter yang mempengaruhi PSi adalah rapat arus, waktu etsa, tipe larutan etsa, dan jarak antara elektroda. $\mathrm{Si}(111)$ bertipe-n dengan resistivitas 1,5-4,5 $\Omega$.cm digunakan sebagai substrat. Substrat dibersihkan dengan prosedur RCA. Alumunium foil digunakan sebagai kontak substrat. Substrat Si sebagai anoda sedangkan platina sebagai katoda. Larutan etsa adalah HF(40\%) dan etanol (99\%) dengan rasio $1: 1$. Jarak elektroda adalah 1,5; 2,0; dan 2,5 cm. Rapat arus untuk setiap jarak elektroda adalah 10, 30, dan $50 \mathrm{~mA} / \mathrm{cm}^{2}$ dengan waktu etsa tetap yaitu 30 menit. Karakterisasi SEM dan UV-Vis digunakan untuk memperoleh morfologi permukaan dan reflektansi dari PSi. Untuk semua sampel, nilai reflektansi PSi lebih rendah daripada Si tanpa perlakuan etsa. Kondisi seperti ini menunjukkan bahwa PSi cocok digunakan 
sebagai anti-reflektif dalam piranti sel surya. Namun demikian kurva reflektansi tidak beraturan sebagai fungsi panjang gelombang untuk variasi jarak elektroda dan rapat arus. Citra SEM menunjukkan bahwa pori yang terbentuk di atas permukaan Si tidak homogen. Ukuran pori menurun untuk jarak elektroda yang meningkat sedangkan ukuran pori meningkat terhadap peningkatan rapat arus. Hal ini menunjukkan adanya hubungan antara ukuran pori dengan reflektansi pada panjang gelombang tertentu.

Kata kunci: Anodisasi, Reflektansi, Silion berpori, Si(111)

\section{INTRODUCTION}

Porous silicon (PSi) technology has been developed in various applications such as gas sensors, humidity sensors, LEDs, optical resonance, disease diagnostics, etc. [1]. PSi inside a solar cell can be used effectively as an anti-reflective layer [2]. Since 1956, more than twenty methods have been developed to fabricate porous silicon such as anodic etching, stain etching, photoetching, metal-assisted etching, vapor etching, reactive-ion etching, spark erosion, laser-induced plasma erosion, oxidation of Rochow reaction by-product, ion implantation, plasma hydrogenation, laser ablation, high-density plasma deposition of silicon, oblique-angle deposition, unidirectional solidification of molten silicon, porous silica reduction, dealloying, laser-induced silane decomposition, electrodeposition, mechanical synthesis, annealing of ultrathin films of amorphous silicon, and using the sacrificial template [3]. Anodic etching or electrochemical anodization method is widely used in making porous silicon because of its low cost and ease to use.

In the previous study, we fabricated PSi on n-type $\mathrm{Si}(100)$ and n-type $\mathrm{Si}(111)$ using the electrochemical anodization method $[4,5]$ and using the reactive ion etching $[6,7]$. The pore shape was inhomogeneous circular and triangle formed on $\mathrm{Si}(100)$ and $\mathrm{Si}(111)$, respectively, using electrochemical anodization method while homogeneous in pore shape and pore size formed on both $\mathrm{Si}(100)$ and $\mathrm{Si}(111)$ using a reactive ion etching method. In this research, we have been used the electrochemical anodization method. The parameters including current density, etching/anodization time, type of etching solution, and electrode distance are the determinants of the pore results in the electrochemical anodization method so that further research is needed [8]. Therefore, in this research, we focused on the variation of current density and electrode distance in the formation of PSi on n-type $\mathrm{Si}(111)$.

\section{EXPERIMENTAL METHOD}

PSi was made using the electrochemical anodization method. A piece of n-type silicon wafer with an orientation of (111) and resistivity of 1.5-4.5 $\Omega . \mathrm{cm}$ was cut into rectangular shape with the size of $1.5 \times 1 \mathrm{~cm}$. The RCA cleaning procedure was used in the cleaning process of the silicon samples. An aluminum foil was stuck in a part of the silicon surface for a conductive contact. The Si sample (anode) and Pt (cathode) were put in an etching solution made from a mixture of HF (40\%) and ethanol (99\%) with a ratio of $1: 1$. The electrode distances (the distance between $\mathrm{Si}$ and $\mathrm{Pt}$ ) were $1.5 \mathrm{~cm}, 2 \mathrm{~cm}$, and $2.5 \mathrm{~cm}$. The current density was varied at 10 $\mathrm{mA} / \mathrm{cm}^{2}, 30 \mathrm{~mA} / \mathrm{cm}^{2}$, and $50 \mathrm{~mA} / \mathrm{cm}^{2}$ and applied for each electrode distance. The times during anodization was maintained for $30 \mathrm{~min}$. The etched silicon was rinsed using piranha solution before being characterized using SEM and UV-Vis Spectrophotometers to obtain surface morphology and reflectance values. 


\section{RESULTS AND DISCUSSION}

PSi has been successfully formed by the electrochemical anodization method. Figure 1 shows the SEM images of PSi with the varied electrode distance and current density. For all samples, the pores are triangle shape and unevenly distributed on the surface. These results agreed with Asoh et al. [9] and Radzali et al. [10], in which they reported about triangle pores shape and their distribution on $\mathrm{Si}(111)$. Concluded that the low anodic dark current during etching could form the triangular-shaped structure on the hydride-terminated $\mathrm{Si}(111)$ surfaces [11]. Meanwhile, considered that the formation of triangular-shaped pores correlated the characteristic faceted which photo-anodization etching in (111) orientation due to the anisotropy of $\operatorname{Si}(111)$ dissolution [12].

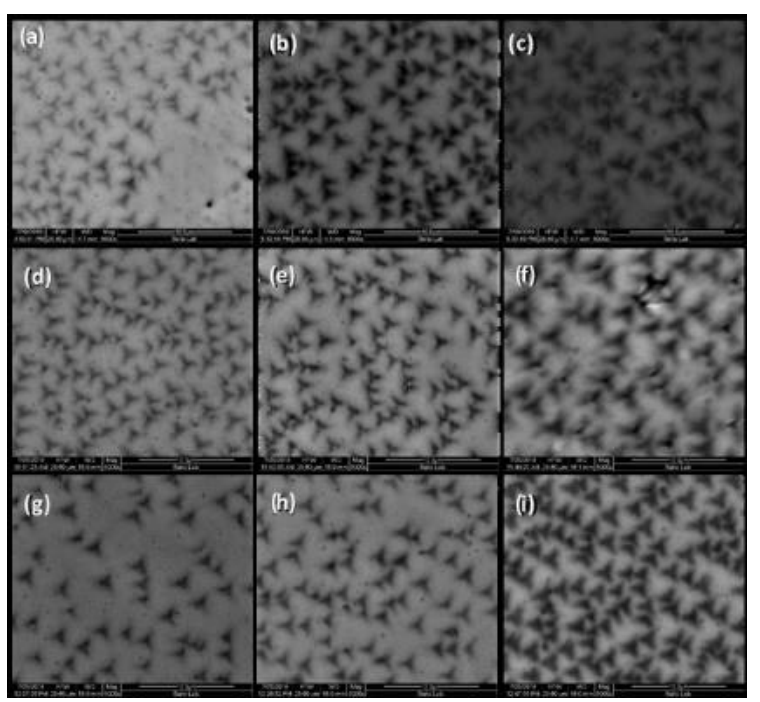

Figure 1. SEM images of PSi after electrochemical anodization for $30 \mathrm{~min}$ with the electrode distance of $1.5 \mathrm{~cm}(\mathrm{a}-\mathrm{c}), 2 \mathrm{~cm}$ (d-f), and 2.5 $\mathrm{cm}(\mathrm{g}-\mathrm{i})$ and the current densities of (a, d, g) $10 \mathrm{~mA} / \mathrm{cm}^{2},(\mathrm{~b}, \mathrm{e}, \mathrm{h}) 30 \mathrm{~mA} / \mathrm{cm}^{2}$, and (c, f, i) $50 \mathrm{~mA} / \mathrm{cm}^{2}$.

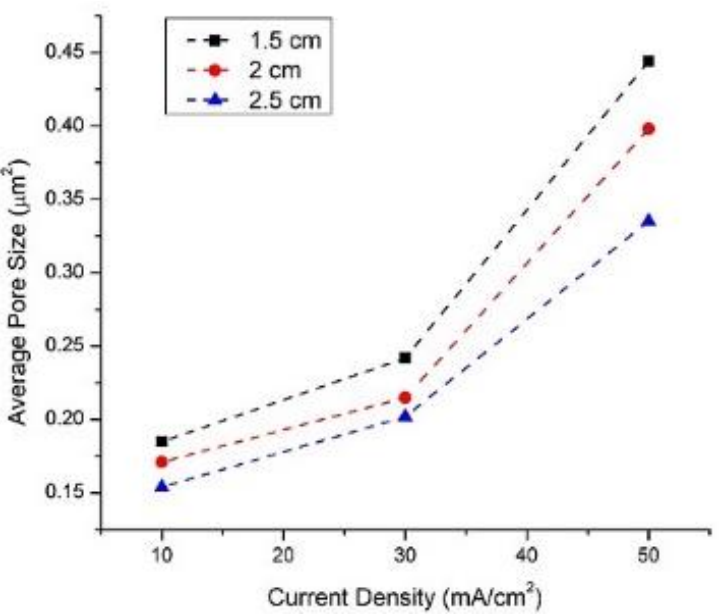

Figure 2. The average pore sizes of PSi after $30 \mathrm{~min}$ etching time with varied current density and electrode distance.

Based on Figure 2, the average pore size decreases with the increasing of the electrode distance while it increases as the current density increases. It is concluded that the formation of a pore in silicon is affected by the current density. The space-charge region (SCR) will be formed at the end of the silicon pore in a line shape when the current has flowed [13]. The electric field will create oxides on the surface of the pores. Then, pores formed exactly where the holes are when the oxide layer is dissolve by the electrolyte solution [8]. Therefore, there is a possibility of applying high-efficiency etching, which is changing high current density for smaller electrode distances in the making of porous silicon.

Figure 3 shows the reflectance values of PSi with varied electrode distance and current density. For all samples, the reflectance value of PSi was found to be lower than the original silicon (before etching). The reducing reflectance approves the potential of the PSi application to be an anti-reflective layer. 

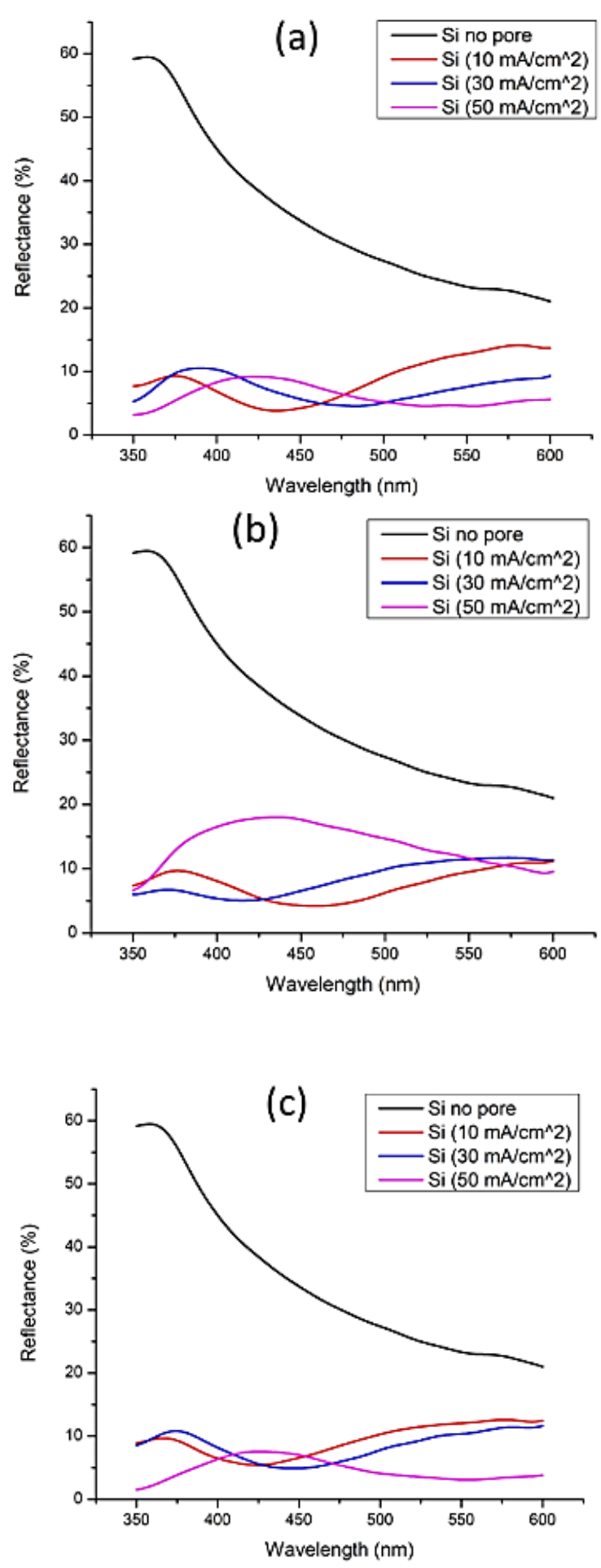

Figure 3. The reflectance value of silicon and PSi with varied current density and the electrode distance of (a) $1.5 \mathrm{~cm}$, (b) $2.0 \mathrm{~cm}$, and (c) $2.5 \mathrm{~cm}$.
The curves of the reflectance values of PSi in Figure 3 show that the reflectance values are changed (up and down) at any wavelength numbers, which indicates the presence of the PSi layer $[14,15]$. However, all sample of reflectance does not show the oscillations. It is considered the high pore density produced during PSi formation [15] or the inhomogeneous pore distribution on the silicon surface. Meanwhile, it can be seen that the reflectance diminishes as the pore size increments.

\section{CONCLUSION}

PSi has been successfully formed on Si(111) surfaces using the electrochemical anodization method with varied current density for each electrode distance. The average pore size decreases as the increase of electrode distance and it increases as the current density increases. The low reflectance values of PSi make it possible as an anti-reflective layer. There is a correlation between pores size and reflectance at a particular wavelength - the pores size growths as the reflectance shrinkages.

\section{REFERENCE}

[1] L. Canham, "Handbook of Porous Silicon", Springer Reference, 2014. https://doi.org/ 10.1007/978-3-31905744-6.

[2] M. Aliaghayee, H. Fard, dan A. Zandi, "Development of Macro-Porous Silicon Based Dye-Sensitized Solar Cells with Improved Light Trapping", Journal of Electrochemical Science and Technology, 7(3), 218-227, 2016. https://doi.org/10.5229/JECST.2016.7 .3.218.

[3] F. Karbassian, "Porous Silicon", Porosity - Process, Technologies and Applications, 3-36, 2018. https://doi.org/10.5772/intechopen.72 910. 
[4] R. Suryana, D. K. Sandi, dan O. Nakatsuka, "The Morphological Study of Porous Silicon Formed by Electrochemical Anodization Method", IOP Conference Series: Materials Science and Engineering, 333(1), 2018. https://doi.org/ 10.1088/1757-899X/333/1/012034.

[5] M. Handayani, N. D. Pratiwi, dan R. Suryana, "Optical Absorbance of Porous Silicon on N-Type Si (111) Surfaces Fabricated by Electrochemical Anodization Method", Materials Today: Proceedings, 13, 87-91, 2019. https://doi.org/10.1016/j.matpr.2019.0 3.193.

[6] R. Suryana, N. D. Pratiwi, M. Handayani, M. Santika, dan O. Nakatsuka,"Patterned Porous Silicon Prepared by Reactive Ion Etching Technique", IOP Conference Series: Materials Science and Engineering, 578(1), 2019. https://doi.org/10.1088/ 1757-899X/578/1/012019.

[7] N. D. Pratiwi, M. Handayani, R. Suryana, dan O. Nakatsuka, "Fabrication of Porous Silicon Using Photolithography and Reactive Ion Etching (RIE)", Materials Today: Proceedings, 13, 92-96, 2019. https://doi.org/10.1016/j.matpr.2019.0 3.194.

[8] N. Burham, A. A. Hamzah, dan B. Y. Majlis," Self-Adjusting Electrochemical Etching Technique for Producing Nanoporous Silicon Membrane", New Research on Silicon - Structure, Properties, Technology, 2017. https://doi.org/10.5772/67719.

[9] H. Asoh, K. Fujihara, dan S. Ono, "Triangle Pore Arrays Fabricated on Si (111) Substrate by Sphere Lithography Combined with MetalAssisted Chemical Etching and Anisotropic Chemical Etching. Nanoscale Research Letters, 7(111),
1-8, 2012. https://doi.org/10.1186/ 1556-276X-7-406.

[10] R. Radzali, M. Z. Zakariah, A. Mahmood, A. F. A. Rahim,Z. Hassan, dan Y. Yusof, "The Effect of Ecthing Duration on Structural Properties of Porous Si Fabricated by a New TwoSteps Alternating Current PhotoAssisted Electrochemical Etching (ACPEC) Technique for MSM Photodetector", AIP Conference Proceedings, 1875(1997), 2017. https://doi.org/10.1063/1.4998357

[11] S. E. Bae, Y. S. Youn, dan C. W. Lee, "Potential Dependence of Electrochemical Etching Reaction of Si(111) Surface in a Fluoride Solution Studied by Electrochemical and Scanning Tunneling Microscopic Techniques", Journal of Electrochemical Science and Technology, 11(4), 330-335, 2020. https://doi.org/10.33961/jecst.2020.00 920.

[12] L. S. Chuah, Z. Hassan, dan H. A. Hassan, "Visible-Light Emission Due to Quantum Size Effects in Porous Crystalline Silicon. AIP Conference Proceedings, 1250(111), 385-388, $2010 . \quad$ https://doi.org/10.1063/ 1.3469686 .

[13] J. Carstensen, M. Christophersen, dan H. Foil, "Pore Formation Mechanisms for the Si-HF System", Materials Science and Engineering B: SolidState Materials for Advanced Technology, 69, 23-28, 2010. https://doi.org/10.1016/S09215107(99)00287-1.

[14] P. S. Kumar, dan R. S. Dubey, "Experimental Study of Electrochemically Prepared Porous Silicon as Anti-reflective Material in Solar Cells", International Research Journal of Engineering and Technology (IRJET), 03(12), 478481, 2016. 
R Suryana: Porous Si(111) Fabrication Using Electrochemical Anodization: Effects of Electrode Distance and Current Density

[15] L. P. Lopez, M. A. B. Faustino, N. G. E. Saplagio, A. I. Mabilangan, N. I. F.

Characterization of Electrochemically Cabello, R. O. M.Gonzales, A. A. Salvador, dan A. S. Somintac, "Structural and Optical Etched Porous Silicon", Philippine Journal of Science, 145(1), 9-15, 2016. 